\title{
The Use of Fermented Cocoa Pod in Feed on Performance and Income Over Feed Cost of Local Sheep
}

\author{
Ardina Kharisma, Hasnudi, Tri Hesty Wahyuni ", Armyn Hakim Daulay, and Nurzainah \\ Ginting \\ Animal Production Study Program, Faculty of Agriculture, Universitas Sumatera Utara, Medan, 20155, \\ Indonesia \\ *Email: trihestiwahyuni@yahoo.com
}

\begin{abstract}
Cocoa pod is one of the cocoa processing wastes which can be used as animal feed. The study aims to find the use of cocoa pod which fermented by bioactivator (MOIYL) in feed on performance and Income over feed cost on local sheep. The research was conducted from October - December 2018 using completely randomized design (CRD) with 5 treatments and 4 replications. The experiment used 20 of local sheep weaning with initial body weight of 12.65 $\pm 1 \mathrm{~kg}$. The treatments were P0 ( $80 \%$ field grass $+20 \%$ concentrate), P1 (60\% field grass + $20 \%$ fermented cocoa pod $+20 \%$ concentrate), P2 (40\% field grass $+40 \%$ fermented cocoa pod $+20 \%$ concentrate), P3 (20\% field grass $+60 \%$ fermented cocoa pod $+20 \%$ concentrate), P4 (80\% fermented cocoa pod + concentrate $20 \%)$. The observed of are feeds consumption, average daily gain, feed conversion ratio (FCR), and income over feed cost (IOFC).

The results of this research indicated that utilization of fermented cocoa pod in feed improved the performance of local sheep, ration conversion and Income Over Feed Cost (IOFC). The use of cacao pods fermented with 5\% MOIYL in ration of local sheep weaning could be given to the level of $40 \%$.
\end{abstract}

Keywords : fermented cocoa pod, sheep, performanca, income over feed cost Received 14 May 2019| Revised 17 June 2019 | Accepted 1 August 2019

\section{Introduction}

Feed is one of the most important factors for livestock survival and the biggest cost incurred in livestock business is to feed around $60-70 \%$. Therefore, efforts to reduce feed costs are a necessity and one of the plantation crop wastes that can be used as feed ingredients such as cocoa pods [1]. 
Ruminant animals that are currently quite interesting to develop are sheep, because sheep have high economic value, such as: can breed quickly, adapt easily to different [2].

North Sumatra is a very large center of cocoa plantations, with production of 40,591 tons. The amount of Cocoa Pod itself reaches $70 \%$ which until now is still underutilized as animal feed. The lack of knowledge of farmers in North Sumatra in the utilization of cocoa waste has resulted in the large amount of cacao pod waste being wasted and can cause environmental pollution [3].

Cocoa fruit generally consists of $73.63 \%$ of the skin (cocoa pod), $24.37 \%$ of the seeds (generally in one cocoa fruit consisting of 30-40 cocoa beans) and $2 \%$ placenta (is the epidermis of the cocoa bean wrapper) [4]. While according to [5] that the cocoa pod contained cellulose $36.23 \%$, hemicellulose $1.14 \%$ and lignin $20 \%-27.95 \%$. Lignin which binds to cellulose causes cellulose cannot be used by livestock.

In the fermentation process there is a breakdown of complex compounds such as cellulose, hemicellulose, silica, by certain enzymes so as to reduce the crude fiber content and increase the digestibility of the material. For improving the quality of feed ingredients for animal feed a treatment is carried out, namely the fermentation technique using various microorganisms which should fit with type of feed ingredients [6]. In this research, microorganisms were used,i.e. Indigenous YL Microorganisms (MOIYL) which were local microorganisms originating from oil palm plantation wastes that have the potential to degrade fibers [7].

Efforts that can be made to increase the productivity of sheep are to provide adequate feed for basic living and production and to keep livestock in healthy condition, where healthy livestock can show good performance [8].

Based on the description above, the researcher was interested in knowing how far the influence of the provision of Pod Cocoa waste fermented with MOIYL on rations on feed consumption, weight gain, feed conversion and Income over feed cost (IOFC) in local sheep.

\section{Methods}

This research was conducted at Mr. Didit's sheep farm located on Jl. Bunga Rinte, Simpang Selayang, Medan. The study lasted for 3 months starting in October - December 2018.

The method used in this study used 20 male local sheep with an average initial body weight of $12.65 \pm 1 \mathrm{~kg}$. The feed ingredients used are forage, and concentrate materials such as coconut cake, soybean meal, rice bran, molasses, urea, mineral mix, and MOIYL as a fermentator. The animals are placed in individual cages of 20 units and their equipment. To weigh livestock, a weight scale of $50 \mathrm{~kg}$ is used with a sensitivity of $10 \mathrm{~g}$, while weighing feed is used with a scale of $2 \mathrm{~kg}$ with a sensitivity of $5 \mathrm{~g}$. 
The research method used a completely randomized design (CRD) consisting of 5 treatments and 4 replications. The treatment given is the level of giving fermented cocoa pods as follows:

P0 : Forage $80 \%+$ Concentrate $20 \%$

P1 : Forage $60 \%$ + Pod cocoa fermented $20 \%$ + Concentrate $20 \%$

P2 : Forage 40\% + Pod cocoa fermented $40 \%$ + Concentrate $20 \%$

P3 : Forage $20 \%+$ Pod cocoa fermentation $60 \%$ + Concentrate $20 \%$

P4 : $80 \%$ fermented cocoa pod $+20 \%$ Concentrate

The research parameters were feed consumption, daily body weight, feed conversion, income over feed cost (IOFC) :

\section{Feed consumption}

Is calculated by weighing the amount of feed given minus the remaining feed during the study stated in (g/head/day).

2. Daily body weight

Was measured by subtracting the difference in final weight by the initial weight divided by the length of the study period.

3. Feed conversion

Is calculated by dividing the amount of feed consumed with daily body weight gain.

4. Income over feed cost (IOFC)

Is calculated by calculating income obtained from livestock body weight (the difference from the final weight with initial weight and multiplied by the selling price) and reduced by the cost of feed (total consumption times the price of feed).

\section{Results and Analysis}

\subsection{Feed Consumption in Dry Materials (g/head/day)}


Table 1. Average feed consumption (dry ingredients) of male local sheep during the study (g/head/day)

\begin{tabular}{|c|c|c|c|c|c|c|}
\hline \multirow{2}{*}{ Treatment } & \multicolumn{4}{|c|}{ Repeat } & \multirow{2}{*}{\multicolumn{2}{|c|}{ Average \pm sd }} \\
\hline & U1 & $\mathrm{U} 2$ & U3 & $\mathrm{U} 4$ & & \\
\hline P0 & 402.32 & 393.68 & 443.15 & 447.33 & $421.62^{b}$ & \pm 27.55 \\
\hline $\mathrm{P} 1$ & 407.95 & 415.24 & 461.12 & 406.11 & $422.60^{\mathrm{b}}$ & \pm 25.97 \\
\hline $\mathrm{P} 2$ & 561.36 & 511.38 & 547.45 & 477.53 & $524.43^{\mathrm{a}}$ & \pm 37.69 \\
\hline P3 & 438.28 & 422.76 & 491.72 & 454.27 & $451.75^{b}$ & \pm 29.58 \\
\hline P4 & 360.27 & 345.68 & 367.89 & 360.09 & $358.48^{\mathrm{c}}$ & \pm 9.27 \\
\hline Average & 434.03 & 417.74 & 462.26 & 429.06 & 435.77 & \pm 18.92 \\
\hline
\end{tabular}

The results of the diversity analysis in Table 1 show $(\mathrm{P}<0.01$ ), so it can be concluded that the provision of fermented cocoa pods has a significant effect on the consumption of male local sheep. It can be assumed that the feed for each treatment responds not to the same quality to consumption.

Feed consumption in treatments P0, P1, P2, P3 and P4 shows a good increase where the highest consumption is found in treatment P2 compared to treatment P4 which has the lowest consumption. In this case it can be seen that each sheep has a different ability to consume and digest the feed given. In addition, the level of preference for sheep is different at each level where in treatment P4 (level 80\%) tends to decrease, and in treatment P2 (level 40\%) has the best consumption compared to other treatments. According to [9] that the level of consumption differences was influenced by several livestock factors (body weight, age, feed digestibility, feed quality and palatability). Good quality food has a higher consumption level than low quality food, so the quality of feed is relatively the same, so the level of consumption is also different. [10] also stated that food consumption will increase if fast food flow or if given high digestibility food and small particle sizes, while cocoa pod fermentation is known to have simpler food particles so that it is easy to be digested and have high palatability.

The difference in the level of consumption between P2 and P4 treatment is also caused by the fact that livestock consume feed in the form of a combination of forage and concentrate. This is in accordance with [11] statement, whom stated that the ration of ruminants is generally forage and concentrate, the provision of rations in the form of a combination of both materials will provide an opportunity for the fulfillment of nutrients. But the ration can also consist of forage or concentrate only. If the ration only consists of forage, the costs are relatively cheap, but high production is difficult to achieve. While the provision of rations that consist only of concentrates will allow high production, but the cost of rations is relatively expensive and may 
cause digestive disorders. This shows that the high feed consumption in P2 treatment because sheep can digest feed given both forage and concentrate optimally.

The low feed consumption at P4 (level 80\%) is also due to the presence of anti-nutrients in the form of theobromine and tannins found in the cocoa pod, according to the statement of [12] whom stated that theobromine is a harmless alkaloid that can be damaged by heating or drying, but feeding which contains theobromine continuously can reduce growth. The high content of lignin and silica also causes low digestibility. [13] also stated that the presence of tannins can form complex bonds with proteins and carbohydrates which results in the rumen microbial activity in degrading protein and carbohydrates to be reduced, thereby reducing digestibility.

\subsection{Daily Body Weight}

Table 2. Average increase in body weight of male local sheep during research $\mathrm{g} / \mathrm{head} / \mathrm{day}$

\begin{tabular}{|c|c|c|c|c|c|c|}
\hline \multirow{2}{*}{ Treatment } & \multicolumn{4}{|c|}{ Repeat } & \multirow{2}{*}{ Average } & \multirow{2}{*}{$\pm \mathrm{sd}$} \\
\hline & U1 & $\mathrm{U} 2$ & U3 & $\mathrm{U} 4$ & & \\
\hline $\mathrm{P} 0$ & 61.60 & 54.64 & 56.25 & 67.32 & $59.95^{b}$ & \pm 5.74 \\
\hline P1 & 47.50 & 51.25 & 78.21 & 66.07 & $60.75^{\mathrm{b}}$ & \pm 14.12 \\
\hline $\mathrm{P} 2$ & 106.78 & 64.46 & 96.25 & 69.28 & $84.19^{\mathrm{a}}$ & \pm 20.55 \\
\hline P3 & 66.60 & 67.32 & 72.50 & 64.64 & $67.76^{\mathrm{ab}}$ & \pm 3.55 \\
\hline P4 & 38.03 & 40.71 & 38.75 & 44.82 & $40.57^{c}$ & \pm 2.63 \\
\hline Average & 55.67 & 55.67 & 68.39 & 62.42 & 62.64 & \pm 9.28 \\
\hline
\end{tabular}

The results of the diversity analysis in Table 2 show ( $\mathrm{P}<0.01$ ), so it can be concluded that the provision of fermented cacao pods has a significant effect on the body weight gain of male local sheep. The provision of feed containing unfermented and fermented cocoa pods increases body weight gain. In P2 treatment with a level of $40 \%$ body weight gain is more optimal because of the balance of feed ingredients, so that the aroma and palatability are very favored by livestock and feed can be digested optimally.

In treatment P4 it gives low results compared to other treatments. This is because at the time of the study there was a change in temperature in the research environment which affected the appetite of livestock. This is in accordance with the statement of [14] whom stated that an increase in temperature and humidity in the environment can cause a decrease in feed consumption, so that the higher the temperature and humidity of a place tends to reduce livestock productivity. Slow body weight gain is caused by inefficient use of energy for growth. According to [15] livestock health was very influenced by feed consumption. Cattle that are sick even though the symptoms are unclear, their appetite goes down and tend to be lazy to walk 
to the place of food or drink in a higher than required environment, appetite will decrease and water consumption will increase.

Different body weight gain due to different amount of feed consumption. Increased sheep body weight is influenced by the amount of feed consumed by livestock. This is in accordance with the statement of [16] whom stated that body weight is always proportional to the level of feed consumption. Feed consumption will provide an overview of the nutrients obtained by livestock so that it affects animal body weight gain during fattening.

\subsection{Feed Conversion}

Table 3. Average feed conversion of male local sheep during the study

\begin{tabular}{lccccccc}
\hline & \multicolumn{5}{c}{ Repeat } & & \multicolumn{2}{l}{ Average \pm sd } \\
\cline { 2 - 5 } Treatment & $\mathrm{U} 1$ & $\mathrm{U} 2$ & $\mathrm{U} 3$ & $\mathrm{U} 4$ & & \\
\hline P0 & 6.53 & 7.20 & 7.87 & 6.64 & $7.06^{\mathrm{b}}$ & \pm 0.53 \\
P1 & 8.58 & 8.10 & 5.89 & 6.14 & & $7.17^{\mathrm{b}}$ & \pm 1.17 \\
P2 & 5.25 & 7.93 & 5.68 & 6.89 & & $6.43^{\mathrm{b}}$ & \pm 1.05 \\
P3 & 6.58 & 6.27 & 6.78 & 7.02 & & $6.66^{\mathrm{b}}$ & \pm 0.27 \\
P4 & 9.47 & 8.49 & 9.49 & 8.03 & & $8.87^{\mathrm{a}}$ & \pm 0.63 \\
\hline Average & 7.28 & 7.59 & 7.14 & 6.96 & 7.24 & \pm 0.73 \\
\hline
\end{tabular}

The results of the analysis of feed conversion diversity showed significantly different effects ( $P$ $<0.05)$ on feed conversion. This is because the results of the analysis of variance in dry matter consumption and daily body weight gain are also significantly different. Because the size of feed conversion depends on the size of feed consumption and weight gain. This is in accordance with the statement of [17] whom stated that feed conversion is the ratio between the amount of feed consumed at a certain time and the production produced in the same time period, the lower the number In treatment P2 has a low conversion value, this is because this treatment has the highest feed consumption with a high body weight gain and with a lower conversion rate also shows that the utilization of fermented cocoa pods is more efficient. This is in accordance with the statement of [18] whom stated that the efficiency of the ration depends on the amount of consumption of dry matter which is able to provide weight gain. A ration will be more efficiently used if the ration is consumed in small amounts and is able to provide a large body weight gain. This is also in line with [19] statement, whom stated that ration conversion rates indicate the level of ration usage where if the conversion rate gets smaller then the use of rations is more efficient and conversely if the conversion rate is large then the use of rations is inefficient. 
In this study we can see that each treatment has a different conversion value, this is caused by several factors that influence feed conversion, namely the environment, animal genetic ability, and the quality of feed provided. According to [20] that several factors that influence feed efficiency included age, feed quality and body weight. The better quality of feed, the better the efficiency of energy formation and production. This is in line with the statement of [21] feed conversion is measured by the amount of dry material consumed divided by the weight gain of the time unity body. Feed conversion especially in ruminants is influenced by feed quality, body weight gain and digestibility value. By providing good quality feed, livestock will grow faster and better feed conversion

\subsection{Income Over Feed Cost (IOFC)}

Table 4. Average income over feed cost (IOFC) of male local lamb (Rp./Tail)

\begin{tabular}{|c|c|c|c|c|c|}
\hline \multirow{2}{*}{ Treatment } & \multicolumn{4}{|c|}{ Repeat } & \multirow{2}{*}{ Average } \\
\hline & U1 & $\mathrm{U} 2$ & U3 & U4 & \\
\hline P0 & $146.973,22$ & $128.021,66$ & $129.382,61$ & $160.117,69$ & $141.123,8^{b}$ \\
\hline P1 & $106.658,93$ & $116.688,14$ & $189.226,28$ & $158.778,17$ & $142.837,9^{b}$ \\
\hline $\mathrm{P} 2$ & $262.124,78$ & $146.908,41$ & $233.538,77$ & $162.631,99$ & $201.301,0^{\mathrm{a}}$ \\
\hline P3 & $157.218,88$ & $160.255,82$ & $170.148,51$ & $150.650,75$ & $159.568,4^{\mathrm{ab}}$ \\
\hline P4 & $82.027,20$ & $90.518,19$ & $83.509,91$ & $101.039,54$ & $89.273,7^{\mathrm{c}}$ \\
\hline Average & $151.000,60$ & $128.478,44$ & $161.161,21$ & $146.643,62$ & $141.123,8^{b}$ \\
\hline
\end{tabular}

The difference in IOFC values in each treatment is influenced by the difference between the price of male local sheep per $\mathrm{Kg}$ sold and the ration cost incurred for production is also different so that the IOFC value for each treatment is also different.

The selling price of sheep is IDR $50,000 / \mathrm{Kg}$ after the maintenance period. Revenue is obtained from multiplying body weight with the selling price of sheep in live weight, while the cost of feed is the amount of costs incurred to produce an increase in the body weight of the sheep. The price of feed used in this study is based on the dry matter of each treatment, namely P0 feed of Rp. 1.133, - / kg, P1 feed is Rp. 1,153 - / kg, P2 feed is Rp. 1,173 - / kg, P3 feed is Rp. 1,193, - / $\mathrm{kg}$ and $\mathrm{P} 4$ feed of Rp. 1,213, - / kg.

The analysis of the diversity of income over feed cost (IOFC) shows that there is a very significant effect $(\mathrm{P}<0.01)$ on feed conversion. In treatment $\mathrm{P} 2$ has the highest IOFC value because $\mathrm{P} 2$ produces a high body weight gain and a low feed conversion value, so the costs are more efficient. And the treatment of P4 produces the lowest IOFC due to the low weight gain of sheep with high conversion values. This is in accordance with [22] statement, whom stated that 
the factors that have an important influence on the calculation of IOFC are body weight gain during fattening, feed consumption and feed prices. Good growth does not necessarily guarantee maximum profits, but good growth and followed by good feed conversionas well as the minimum cost of feed that will get maximum profit.

\section{Conclusion}

It is conclusion to provide fermented cocoa pods as male local animal feed fermented with MOIYL by $40 \%$ in rations.

\section{References}

[1] Murtisari, T. 2005. Pemanfaatan Limbah Pertanian Sebagai Pakan untuk Menunjang Agribisnis Domba. Lokakarya Nasional Potensi dan Peluang Pengembangan Usaha domba. Bandung: 30 September 2005.

[2] Soedjana, T.D. 2007. Prevalensi Usaha Ternak Tradisional dalam Perspektif Pembangunan Peternakan Menghadapi Pasar Global. Pengembangan Inovasi pertanian 4(2): 156-173.

[3] Dinas Perkebunan Provinsi Sumatera Utara. 2016. Produksi Coklat Tanaman Perkebunan Rakyat Menurut Kabupaten. Badan Pusat Statistik Provinsi Sumatera Utara. Medan.

[4] Siswoputranto, P.S. 1983. Budidaya dan Pengolahan Cokelat. Balai Penelitian Bogor, Sub Balai Penelitian Budidaya. Jember.

[5] Amirroenas, D.E. 2003. Mutu Ransum Berbentuk Pellet dengan Bahan Serat Biomassa pada Coklat (Theobroma cacao L.) untuk Pertumbuhan Domba Jantan. Tesis. Fakultas Pasca sarjana, Institut Pertanian Bogor. Bogor.

[6] N Ginting.2018. Comparison of isolate dadih with yeast dadih in improving nutrition quality of Cassava Waste (CW). IOP Conf Series: Earth and Env Science 141 (2018) 012008

[7] Yunilas. 2016. Peran Mikroorganisme Indigenous YL (MOIYL) Sebagai Inokulum Pendegradasi Serat Berbasis Limbah Perkebunan Sawit. Prosiding Seminar nasional Peternakan Berkelajutan 8. 16 November 2016.

[8] Hakim, L.M. 2013. Pemeliharaan Domba. Fakultas Peternakan dan Pertanian. Universitas Diponegoro. Semarang.

[9] Parakkasi, A. 1995. Ilmu Nutrisi dan Makanan Ternak Ruminansia. UI Press. Jakarta.

[10] Arora, S.P. 1989. Pencernaan Mikrobia pada Ruminansia. Gadjah Mada University Press. Yogyakarta.

[11] Siregar, S.B. 1994. Ransum Ternak Ruminansia. Penebar Swadaya. Jakarta. 
[12] Oluokun, J.A. 2005. Intake, Digestion and Nitrogen Balance of Diets Blanded with Urea Treated and Untreated Cowpea Husk by Growing Rabbit. African J Biotechnol. 4: 12031208.

[13] Puastuti, W., D. Yulistiani, dan D. Suasana. 2014. Evaluasi Nilai Nutrisi Bungkil Inti Sawit yang Difermentasi dengan Kapang Sebagai Sumber Protein Ruminansia. Balai Penelitian Ternak, Bogor. Vol. 19 No. 2. 143-151.

[14] Hamdan, A. 2007. Konsumsi Pakan dan Pertambahan Bobot Badan Domba yang diberi Jerami Padi. Jurnal Pengembangan Peternakan Tropis.

[15] Hardjosworo, P.S., dan Rukmiasih, M.S. 2000. Meningkatkan Produksi daging. Penebar Swadaya. Yogyakarta.

[16] Kartadisastra, H.R 1997. Penyediaan dan Pengelolaan Pakan Ternak Ruminansia. Kanisius. Yogyakarta.

[17] Anggorodi, R. 1990. Ilmu Makanan Ternak Umum. PT. Gramedia. Jakarta.

[18] Tillman, A.D., H. Hartadi., S. Reksohadiprojo., S. Prawirokusumo., dan S. Labdosukojo. 1991. Ilmu Makanan Ternak Dasar. Gadjah Mada University Press. Yogyakarta.

[19] Campbell, W. 1984. Principles of Fermentasion Technology. Peragaman Press. New York.

[20] Pond, W.G., D. Cruch dan K.R. Pond. 2005. Basic Animal Nutrition. New York.

[21] Martawidjaya, M. 1999. Pengaruh Pencukuran dan Pemberian Konsentrat Terhadap Performans Domba Jantan Muda. Jurnal Ilmu dan Peternakan, 2 (4) : 163-166.

[22] Kasim. 2002. Performa Domba Lokal yang Diberi Ransum Komplit Berbahan Baku Jerami dan Onggok yang Mendapat Perlakuan Cairan Rumen. Skripsi. Fakultas Peternakan. Institut Pertanian Bogor. Bogor. 